\title{
Modeling of the Adiabatic and Isothermal Methanation Process
}

\author{
Jekaterina Porubova ${ }^{1}$, Gatis Bazbauers ${ }^{2}$, Darja Markova ${ }^{3},{ }^{1-3}$ Riga Technical University, \\ Institute of Energy Systems and Environment
}

\begin{abstract}
Increased use of biomass offers one of the ways to reduce anthropogenic impact on the environment. Using various biomass conversion processes, it is possible to obtain different types of fuels:

- solid, e.g. bio-carbon;

- liquid, e.g. biodiesel and ethanol;

- gaseous, e.g. biomethane.

Biomethane can be used in the transport and energy sector, and the total methane production efficiency can reach $65 \%$. By modeling adiabatic and isothermal methanation processes, the most effective one from the methane production point of view is defined. Influence of the process parameters on the overall efficiency of the methane production is determined.
\end{abstract}

Keywords - biomethane, methanation, Aspen Plus®, modeling

\section{INTRODUCTION}

Methanation is one of the process stages that transforms solid fuel into a gaseous form, and, as a result, biomethane is produced. The field of biomethane use might be both the transport and energy sectors, since biomethane is easy to transport and store via the existing natural gas distribution networks and storage ranges [7, 8]. Lignin substances (wood and its residues) can be used as raw materials for biomethane production and the total production efficiency is above $65 \%$. Future projections indicate that biomethane production plants could be in the medium power range between 20 to $100 \mathrm{MW}$ and become industrially available around 2020 $[11,12]$.

The collective target that is set between the member states of the European Union for renewable energy usage is defined in Directive 2009/28/EC [3]. The main aim of Directive $2003 / 30 / \mathrm{EC}$ is to stimulate use of biofuel in the transport sector. It defines that the total consumption of biofuel in the transport sector in the EU member states has to reach $2 \%$ in 2005 and $5.75 \%$ in 2010 [1]. The Latvian goal is for biofuel to reach a level of $37 \%$ of the primary renewable energy use in the national energy balance by the year 2016 [2]. The same guidelines, however, had established that in 2010 the amount of the produced electricity from renewable sources (RES) had to reach $49.3 \%$ of the total consumed electricity, but in reality only $48.5 \%$ of the RES were produced [4].

The methane extraction from biomass can occur in two ways and, depending on the chosen extraction method, the operation conditions and the final products can vary [7]:

a) thermo-chemical conversion of biomass, leading to a biomethane;

b) bio-chemical conversion of biomass, leading to a bio-gas.
The main differences between these two methods are that, during the thermo-chemical conversion, biomass gasification is followed by the methanation process, but bio-gas production occurs during the anaerobic digestion of biomass. In addition, thermo-chemical transformation is characterized by a higher efficiency compared to bio-chemical conversion. This higher efficiency leads to a faster transformation response, which is a few seconds or minutes for the thermochemical conversion and several days, weeks or even more for the anaerobic digestion of biomass [11].

Below are the main methanation reactions $[5,6]$ :

$$
\begin{array}{lr}
\mathrm{CO}+3 \mathrm{H}_{2} \leftrightarrow \mathrm{CH}_{4}+\mathrm{H}_{2} \mathrm{O} & \Delta \mathrm{H}_{R}=-206.28 \mathrm{~kJ} / \mathrm{mol} \text { (1.1) } \\
\mathrm{CO}_{2}+4 \mathrm{H}_{2} \leftrightarrow \mathrm{CH}_{4}+2 \mathrm{H}_{2} \mathrm{O} & \Delta \mathrm{H}_{R}=-165.12 \mathrm{~kJ} / \mathrm{mol}(1.2) \\
\mathrm{CO}+\mathrm{H}_{2} \mathrm{O} \leftrightarrow \mathrm{H}_{2}+\mathrm{CO}_{2} & \Delta \mathrm{H}_{R}=-41.16 \mathrm{~kJ} / \mathrm{mol}(1.3) \\
\mathrm{C}_{2} \mathrm{H}_{4}+2 \mathrm{H}_{2} \mathrm{O} \leftrightarrow 2 \mathrm{CO}+4 \mathrm{H}_{2} & \Delta \mathrm{H}_{R}=+210 \mathrm{~kJ} / \mathrm{mol}(1.4)
\end{array}
$$

Reactions (1.1) - (1.3) are exothermic, while the reaction (1.4) requires additional heat input (endothermic character). Since the methanation reactions are revertible, the concentration of methane is constantly increasing, but, bearing in mind the fact that the temperature and pressure are constant, the reaction takes place straight in the direction of the final products [10].

Gaseous product purification and its condensation takes place after the biomass gasification process (Fig. 1). During this process, sulfur, chlorine, solids, ash and carbon dioxide are removed from the total gas flow. Sulfur removal from the flow is based on the fact that the type of catalyst, which is used during the methanation process, is very sensitive to sulfur and its compounds. After the methanation phase, biomethane purification from water vapor, hydrogen and other impurities is obtained, so that the produced fuel will meet the quality requirements, which are imposed on gaseous fuels [13]. There are a variety of technologies to use during the stage of gas purification and condensation, such as cyclones and filters, through which solid particles from the gas flow are isolated. Than the tar condensation appears, as well as further intermediate product temperature decrease occurs. After the methanation process, not only undesirable compounds of biomethane are extracted, but also the drying and temperature decrease is achieved [14]. 


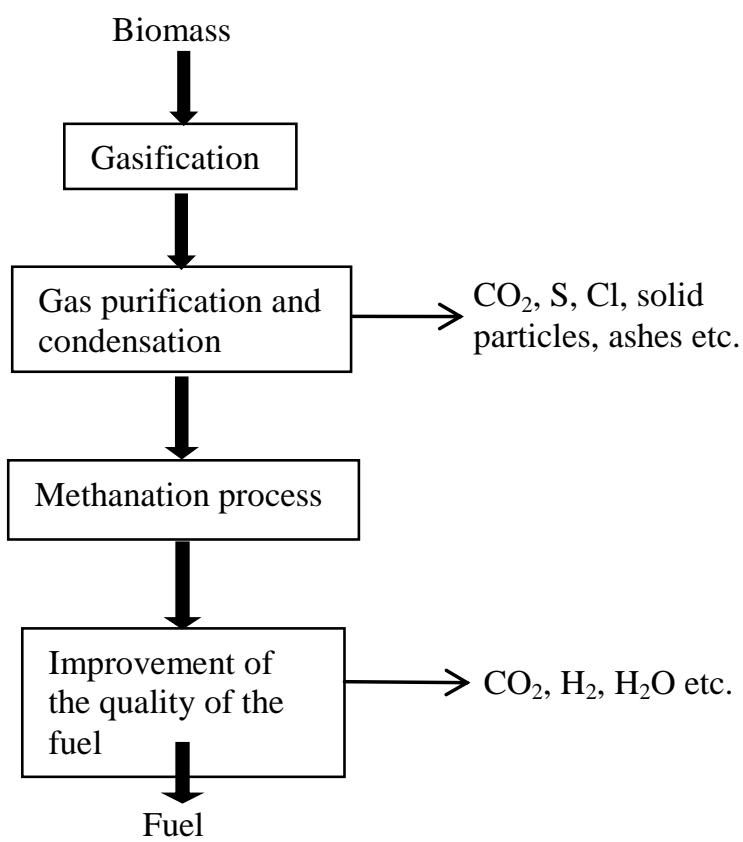

Fig. 1. Principal 1 transformation scheme of solid biomass into biomethane [13].

Table I summarizes the main differences between the two existing methanation processes - adiabatic and isothermal.

TABLE I

THE MAIN DIFFERENCES BETWEEN ISOTHERMAL AND ADIABATIC METHANATION PROCESSES $[21,22,23]$

\begin{tabular}{|l|l|l|}
\hline & $\begin{array}{l}\text { Adiabatic } \\
\text { methanation }\end{array}$ & $\begin{array}{l}\text { Isothermal } \\
\text { methanation }\end{array}$ \\
\hline Type of the reactor & Stationary layer & Boiling layer \\
\hline $\begin{array}{l}\text { Working } \\
\text { temperature, }{ }^{\circ} \mathrm{C}\end{array}$ & $240-600$ & $\sim 300$ \\
\hline Pressure, bar & $20-100$ & $1-20$ \\
\hline Advantages & Simple construction & $\begin{array}{l}\text { Good heat and mass } \\
\text { exchange processes }\end{array}$ \\
\hline Disadvantages & Complex heat transfer & $\begin{array}{l}\text { Working material } \\
\text { maintenance }\end{array}$ \\
\hline
\end{tabular}

As it is shown in Table I, the main differences between the two methanation processes are associated with the reactor type, which is exactly what defines the working conditions of the process (temperature, pressure). The equipment construction and its service also depend on the methanation reactor. The benefits of adiabatic methanation (Table I) are relatively simple equipment construction and maintenance, which is very important, if small (compact) devices are being designed. The purpose of the modeling of the methanation process is to determine how the process and its efficiency (the yield of methane) are affected by changes of the incoming gas composition, specifically, by changes in the amounts of carbon dioxide and nitrogen.

\section{USED METHODS}

Primary modeling allows to estimate and analyze a variety of different process possibilities, and to determine optimal working conditions which are theoretically possible. Thus, the additional costs that might appear in continuous and repeated experiments are avoided. There are several computer programs which can be used in the simulation of various processes; however, the methanation process is more likely to be simulated with Aspen Plus ${ }^{\circledR}$ or CHEMCAD®. Both programs are intended for the modeling of chemical processes and their detailed analysis, as well as the determination of the mass and energy balance, and calculate the energy balance [15].

The following manipulations can be performed with Aspen Plus®:

- simulation of distillation processes,

- modeling a variety of chemical processes by using different types of reactors based on chemical equilibrium conditions,

- carrying out sensitivity analysis for selected parameters,

- combining different equipments to conduct in-depth research of an interested process, etc. [16]

After preparation of the report which is based on the input data, the summarizing table allows to access material and energy flows in each step of the process. Different processes, such as a combined biomass gasification process, were modeled with Aspen Plus®. This process was analysed and optimized, in order to increase the overall energy efficiency. Furthermore, various processes of $\mathrm{CO}_{2}$ absorption were modeled using few substances and their mutual comparison was made, etc. $[18,19,20]$.

Within this work, three methanation process models were created using the Aspen Plus ${ }^{\circledR}$ program:

1. adiabatic methanation (Fig. 2);

2. adiabatic methanation scheme of the $\mathrm{CO}_{2}$ extraction (Fig. 3);

3. isothermal methanation (Fig. 4).

The range of values of the parameters which affect the process and are used in the modeling of all three processes are:

1. $\mathrm{CO}_{2}$ variation range $1.5-30 \%$,

2. $\mathrm{N}_{2}$ variation range $2.2-50 \%$.

Nitrogen was chosen in the analysis because air is commonly used in the gasification process. While the carbon dioxide is directly involved in methanation reactions, there is still no unified opinion on how its concentration change affects the methane yield. At the same time, high nitrogen and carbon dioxide concentrations may dilute the synthesized gas that flows to the methanation reactor, influencing the outcome of the methane. In addition to the dilution of synthesized gas, the competition between $\mathrm{CO}_{2}$ and $\mathrm{CO}$ for hydrogen occurs, which affects energy consumption in the methanation reactor [24]. Table II shows the composition of the synthesized gas before the methanation reactor that was used in all simulation models. 
TABLE II

COMPOSITION OF THE SYNTHESIZED GAS BEFORE METHANATION REACTOR [25]

\begin{tabular}{|c|c|}
\hline Component & Amount, \% \\
\hline $\mathrm{CO}$ & 22 \\
\hline $\mathrm{CO}_{2}$ & 22 \\
\hline $\mathrm{N}_{2}$ & 2 \\
\hline $\mathrm{H}_{2}$ & 39 \\
\hline $\mathrm{CH}_{4}$ & 10 \\
\hline $\mathrm{C}_{2} \mathrm{H}_{6}$ & 5 \\
\hline
\end{tabular}

The principal methanation process scheme created with the Aspen Plus program can be seen in Figures 2-4. Gibb's reactors were used as methanation reactors in all models. It is assumed that there is no pressure loss in the system. The final stage in all models after the methanation process is water removal from the composition of biomethane that is ensured by a flow separator, where the water condensation takes place. The water during methanation is formed within chemical reactions, so, in order to fully represent all processes that occur in simulation, the steam is supplied to the synthesized gas flow upstream of the methanation reactor (see Fig. 2-4).

The most important input parameters that were defined for adiabatic methanation are summarized in Table III. The total synthesized gas flow, steam flow and synthesized gas temperature were assumed.

TABLE III

INPUT PARAMETERS FOR METHANATION PROCESS MODELS

\begin{tabular}{|l|l|c|}
\hline Parameter & $\begin{array}{l}\text { Adiabatic } \\
\text { metanation }\end{array}$ & $\begin{array}{l}\text { Isothermal } \\
\text { metanation }\end{array}$ \\
\hline Methanation pressure, bar & 20 & 2.5 \\
\hline Compressor pressure, bar & \multicolumn{2}{|c|}{1} \\
\hline Input temperature, ${ }^{\circ} \boldsymbol{C}$ & \multicolumn{2}{|c|}{17} \\
\hline Synthesized gas & \multicolumn{2}{|c|}{300} \\
\hline Steam & \multicolumn{2}{|c|}{300} \\
\hline MR1 & 250 & - \\
\hline MR2 & 250 & - \\
\hline MR3 & \multicolumn{2}{|c|}{25} \\
\hline Flow separator & \multicolumn{2}{|c|}{10} \\
\hline Total flow, mmol/s $^{\mid 2}$ & 1 \\
\hline Synthesized gas &
\end{tabular}

Figures 2 and 3 are related to the adiabatic methanation process, and the number of used reactors in this process is higher than in the isothermal process (see Figure 4).

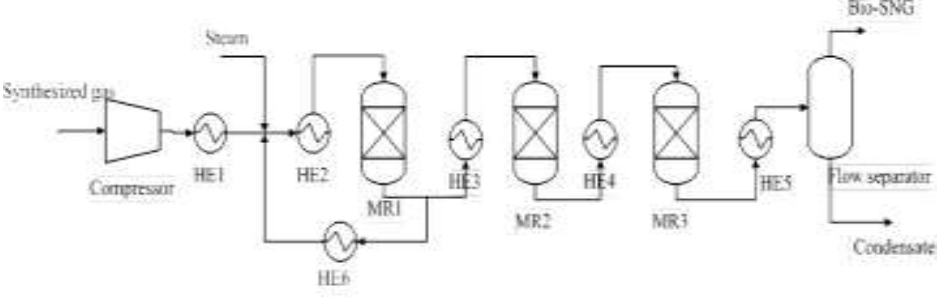

Fig. 2. Adiabatic methanation process scheme ("HE" - heat exchanger, "MR" - methanation reactor).

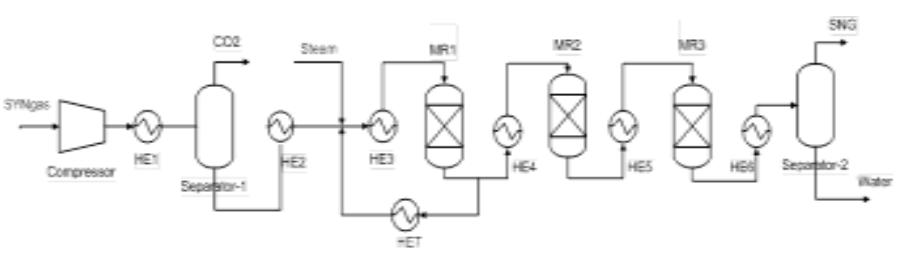

Fig. 3. Adiabatic methanation scheme of the $\mathrm{CO}_{2}$ extraction from the total gas flow.

As it is shown in Figures 2 and 3, the partial gas recirculation, which is necessary due to the temperature regime, takes place downstream of the first methanation reactor. The temperature decrease in the first reactor appears due to the fact that the incoming gas is expanding, which stimulates gas dilution, so that output flow from the MR1 does not require so much gas cooling. In adiabatic methanation, a heat exchanger is used upstream of each reactor (see Fig. 2, 3), since it is necessary that the temperature of input flows in the reactors should be around 250-300 ${ }^{\circ} \mathrm{C}$, but methanation reactions are exothermic. Figure 3 shows the adiabatic methanation scheme of $\mathrm{CO}_{2}$ extraction and, in comparison to Figure 2, all other parameters used have remained unchanged.

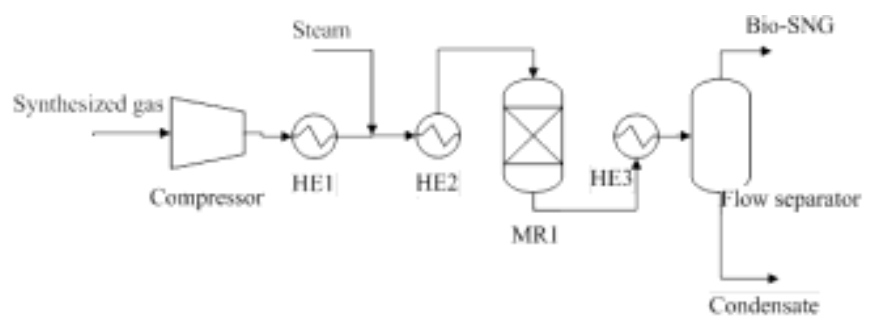

Fig. 4 Isothermal methanation process scheme.

When comparing isothermal (see Fig. 4) and adiabatic methanation (Fig. 2), isothermal methanation requires less heat exchangers, that is obviously explained with the number of methanation reactors (adiabatic process - three, isothermal one), additionally keeping in mind that the isothermal methanation occurs at a constant temperature.

\section{RESULTS AND DISCUSSION}

The gas compositions after methanation are represented in the Table IV. Comparing the biomethane composition with synthesized gas composition after the methanation process (see Table IV), the amount of carbon dioxide significantly increased 
(approximately doubled), while at the same time, almost all hydrogen participated in methanation reactions. As a result, the water has appeared and the methane concentration has increased, and during the methanation reactions the largest part of carbon monoxide has reacted. However, significant differences in the composition of the biomethane produced by these two types of methanation are not observed (Table IV). The main components that take up about $90 \%$ of the produced biomethane remain unchanged and these are $\mathrm{CO}_{2}$ and $\mathrm{CH}_{4}$. These results mean that there is a need for more in-depth research on how changes in synthesized gas composition influence the methanation process, depending on the operating conditions.

\section{TABLE IV}

BIOMETHANE COMPOSITION AFTER THE METHANATION PROCESS-UP THAT OCCURS AFTER CONDENSATE EXTRACTION

\begin{tabular}{|c|c|c|c|c|}
\hline \multirow{2}{*}{ Parameter } & \multicolumn{2}{|c|}{$\begin{array}{c}\text { Adiabatic } \\
\text { methanation }\end{array}$} & \multicolumn{2}{c|}{$\begin{array}{c}\text { Isothermal } \\
\text { methanation }\end{array}$} \\
\cline { 2 - 5 } & kmol/sec & \% & kmol/sec & \% \\
\hline $\mathrm{CH}_{4}$ & 3.413 & 48.4 & 3.426 & 48.8 \\
\hline $\mathrm{CO}_{2}$ & 3.066 & 43.5 & 3.069 & 43.7 \\
\hline $\mathrm{H}_{2} \mathrm{O}$ & 0.226 & 3.2 & 0.225 & 3.2 \\
\hline $\mathrm{N}_{2}$ & 0.2 & 2.8 & 0.2 & 2.9 \\
\hline $\mathrm{H}_{2}$ & 0.126 & 1.8 & 0.093 & 1.3 \\
\hline $\mathrm{CO}$ & 0.02 & 0.3 & 0.005 & 0.1 \\
\hline
\end{tabular}

\section{A. Adiabatic methanation}

$\mathrm{CO}_{2}$ extraction (see Fig. 4 for the principal scheme of the process) from the total synthesized gas flow has a positive impact on the outcome of methane. The higher the level of separation, the higher the flow of methane is (see Fig. 5). Since the modeling of carbon dioxide gas took place under a constant temperature and pressure, it is possible to affirm that $\mathrm{CO}_{2}$ concentration has a significant impact on the methanation process, and there is a direct dependence between the separation level and the methane flow after the first methanation reactor.

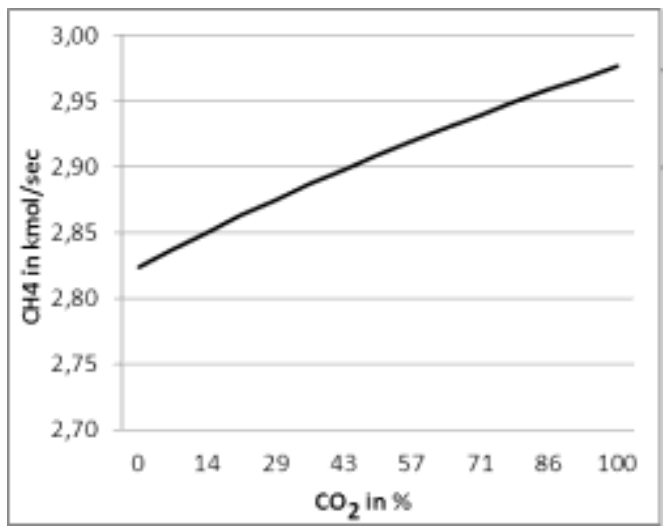

Fig. 5. The influence of the level of $\mathrm{CO}_{2}$ extraction on $\mathrm{CH}_{4}$ flow.

The most rapid increase of methane outcome has been noticed at the outlet from the first and second methanation reactor. Changes of methane flow downstream of the third reactor remain minimal, and the same situation is observed for the methanation temperature changes (see Fig. 6).

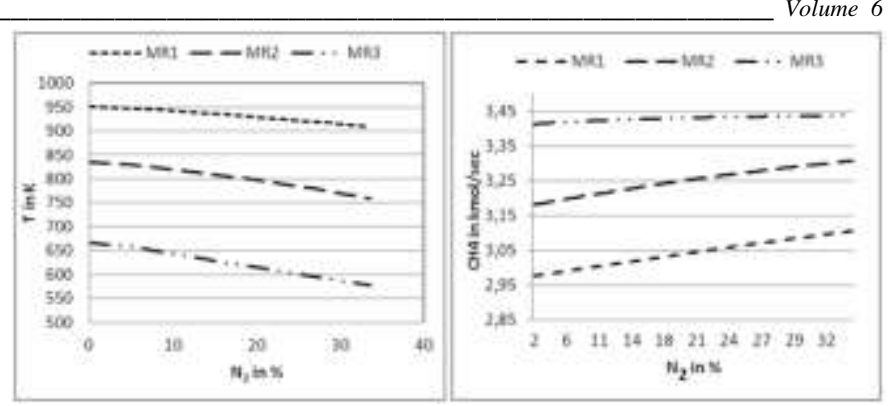

Fig. 6. Influence of changes of nitrogen concentration on temperature of methanation process and methane outcome for adiabatic process.

Furthermore, at the high nitrogen concentration level (around $35 \%$ ), the value of gas temperature can be scaled down up to $100 \mathrm{~K}$, compared with the case where the synthetic gas is completely released from the $\mathrm{N}_{2}$. This temperature reduction means that the synthesized gas diluted with nitrogen can reduce heat flow in the adiabatic methanation process, thus, it is possible to declare that the increase of nitrogen concentration through the decrease of the methanation temperature indirectly impacts methane output and total methanation process efficiency. Synthesized gas is diluted with nitrogen because it is an inert gas, which means that nitrogen does not participate in the methanation reactions due to relatively low temperatures of the reaction processes (around $300^{\circ} \mathrm{C}$ ).

\section{B. Isothermal methanation}

In the case of isothermal methanation, an increase of $\mathrm{CO}_{2}$ concentration only affects the flow of carbon monoxide, and other parameters, such as yield of methane and hydrogen, remain the same.

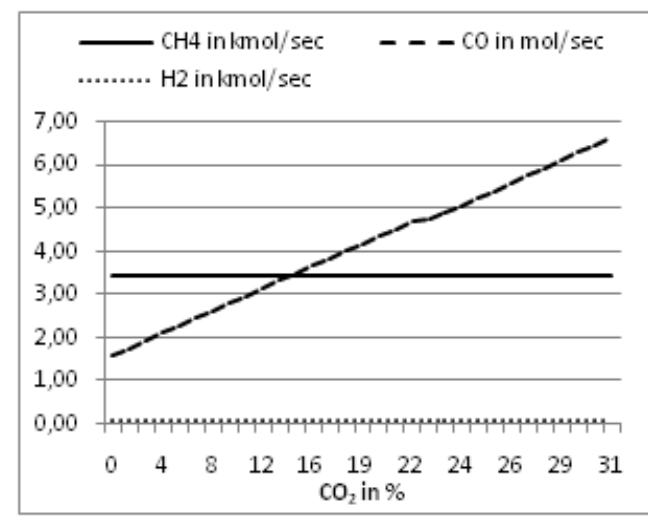

Fig. 7. $\mathrm{CH}_{4}, \mathrm{CO}$ and $\mathrm{H}_{2}$ flow dependence on changes of $\mathrm{CO}_{2}$ concentration.

When comparing the impact of carbon in adiabatic and isothermal methanation cases, it is noticeable that during the adiabatic process, the reduction of $\mathrm{CO}_{2}$ concentration leads to growth of methane output in the biomethane composition. It can be concluded that at the constant temperature changes of $\mathrm{CO}_{2}$ concentration do not affect efficiency of the methanation process efficiency. 


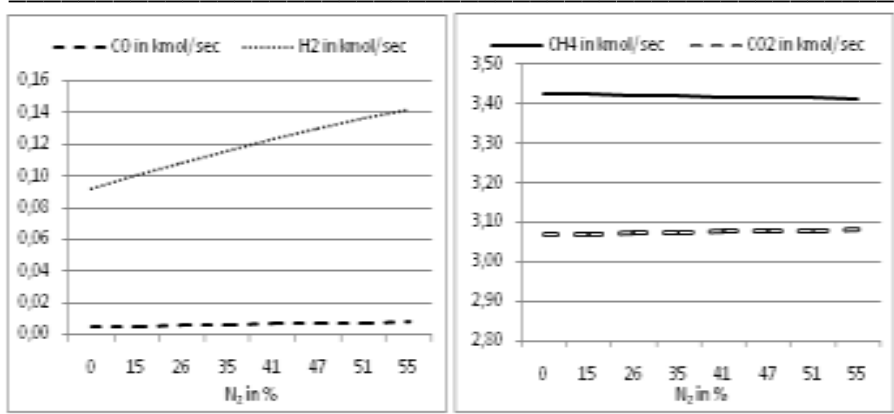

Fig. 8. The changes of $\mathrm{CH}_{4}, \mathrm{CO}, \mathrm{CO}_{2}$ and $\mathrm{H}_{2}$ concentration, depending on the $\mathrm{N}_{2}$ concentration

A similar situation is observed for changes of concentration of nitrogen during isothermal methanation. As it is shown in Figure 8 , the increase of nitrogen in the synthesized gas composition leads to small changes in concentration of $\mathrm{CO}$, $\mathrm{H}_{2}, \mathrm{CH}_{4}$ and $\mathrm{CO}_{2}$. It is also possible to notice the rapid growth of hydrogen, however the outcome of methane tends to decrease.

\section{CONCLUSIONS}

The results of this work indicate that the composition of the synthesized gas has a greater impact on the outcome of methane in adiabatic methanation then in the isothermal process. This impact is indicated by the amount of produced methane and changes of the flow of others components. The most important observation is that synthesized gas diluted with nitrogen does reduce the operating temperatures of methanation in the adiabatic methanation, which stimulates the flow of methane. At the same time, reduction of carbon dioxide concentration just before the start of methanation process also increases the production of methane. The overall conclusion about the effects of nitrogen and carbon dioxide on the methanation process is that the maximum dilution of synthesized gas with nitrogen and the maximum carbon dioxide gas extraction from the synthesized gas maximizes the outcome of methane.

\section{REFERENCES}

1. EIROPAS PARLAMENTA UN PADOMES DIREKTĪVA 2003/30/EK (2003. gada 8. maijs) par biodegvielu un citu atjaunojamo veidu degvielu izmantošanas veicināšanu transportā.

2. Atjaunojamo energoresursu izmantošanas pamatnostādnes 2006.2013.gadam (informatīvā dalıa) Rìga 2006.gads, 55 lpp.

3. DIRECTIVE 2009/28/EC OF THE EUROPEAN PARLIAMENT AND OF THE COUNCIL of 23 April 2009 on the promotion of the use of energy from renewable sources and amending and subsequently repealing Directives 2001/77/EC and 2003/30/EC. L 140/16 EN Official Journal of the European Union 5.6.2009

4. Renewable energy sources http://www.em.gov.lv/em/2nd/?cat=30170 - [02.07.2011]

5. Duret A., Friedli C., Marechal F. Process design of Synthetic Natural Gas (SNG) production using wood gasification, Journal of Cleaner Production, 2005, vol. 13, p. 1434-1446

6. Gasifipedia Supporting Technologies http://www.netl.doe.gov/technologies/coalpower/gasification/gasifipedia 15-support/5-12_methanation.html - [29.03.11]

7. Perimenis A., Walimwipi H., Zinoviev S., Müller-Langer F., Miertus S. Development of a decision support tool for the assessment of biofuels, Energy Policy, 2011, vol. 39,p. 1782-1793
8. Sudiro M. ,Bertucco A., Groppi G., Tronconib E. Simulation of a structured catalytic reactor for exothermic methanation reactions producing synthetic natural gas. In: 20th European Symposium on Computer Aided Process Engineering - ESCAPE20 S. Pierucci and G. Buzzi Ferraris (Editors) (C) 2010 Elsevier B.V. All rights reserved. 6. lp

9. Seiffert M., Kaltschmitta M., Mirandaa J.A. The biomethane potential in Chile, BIOMASS AND BIOENERGY, 2009, vol. 33, p.564 572

10. Tremmel H., Aichernig C. Bio-SNG - Demonstration of the production and utilization of syntetic natural gas (SNG) from solid biofuels. Specific Targeted Research of Innovation project. Deliverable D 4.2 Bio-SNG plant ready to produse BioSNG, 2009,p. 16

11. Zhang L., Xu C. (Charles), Champagne P. Overview of recent advances in thermo-chemical conversion of biomass, Energy Conversion and Management, 2010, vol. 51, p. 969-982

12. Zhang W. Automotive fuels from biomass via gasification, Fuel Processing Technology, 2010, vol. 91, p. 866-876

13. Kopyscinski J. Production of synthetic natural gas in a fluidized bed reactor Understanding the hydrodynamic, mass transfer, and kinetic effects, DISS. ETH NO. 18800, 2010 g., 252 lpp.

14. DARBA DOKUMENTS NEATSPOGUL̨O VALDĪBAS NOSTĀJU Valdības Dekrēts Nr. .../2009. (... ...) Korm. par grozījumiem Valdības dekrētā Nr. 19/2009. (I. 30.) Korm. par prasību ieviešanu, kuras noteiktas ar 2008. gada Likumu Nr. XL par dabasgāzes piegādi, IND20090090 HU- LV- 20090227 PROJECT, 4 lpp.

15. http://www.vtu.com/Prozess-Simulation/de/1515/b/11

16. http://www.tucottbus.de/anls/deutsch/lehrst/software/aspenplus/aspenplus.html

17. Ramzan N, et al., Simulation of hybrid biomass gasification using Aspen plus: A comparative performance analysis for food, municipal solid and poultry waste, Biomass and Bioenergy (2011), doi:10.1016/ j.biombioe.2011.06.005

18. Ruiz G. J., Kim S. B, Moon J. et al. Design and optimization of energy efficient complex separation networks, Computers and Chemical Engineering, 2010, vol. 34, p. 1556-1563

19. Elmalik E. E., Tora E., El-Halwagi M. et al. Solvent selection for commercial supercritical Fischer-Tropsch synthesis process, Fuel Processing Technology, 2011, vol. 92, p. 1525-1530

20. Bajohr S., Baudry A., Götz M. et al. Methanisierung - technische Ansätze und deren Bewertung, International Biomass Conference Leipzig, 04.05.2010

21. Ebbing D.D., Gammon S.D. General Chemistry. Ninth Edition, Cengage Learning, USA, 2007 - 1030 pp.

22. Sudiro M., Zanella C., Bressan L., Fortana M. and Bertucco A., (2009) Synthetic natural gas (SNG) from petcoke: model development and simulation, AIDIC Conference Series, 09, 309-318 DOI:10.3303/ACOS0909036

23. Klemm M., Ortwein A., Zeymer M. et al. 'Gasreinigung und Konditionierung - Stand der Technik und Gesamtkonzepte für Methanisierungsanlage, 1. International Biomass Conference, Leipzig, 4. Mai 2010

24. Heyne S., Seemann M. and Harvey S., (2010), Integration study for alternative methanation technologies for the production of synthetic natural gas from gasified biomass, Chemical Engineering Transactions, 21, 409-414 DOI: 10.3303/CET1021069

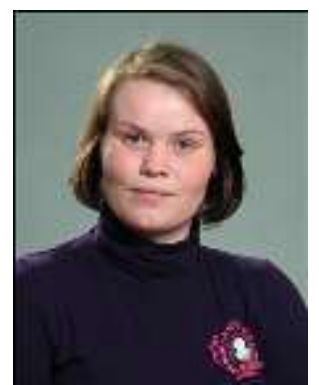

Jekaterina Porubova, M. Sc, PhD student, researcher of Institute of Energy Systems and Environment of RTU. Jekaterina Porubova has been part of academic staff of Faculty of Energy and Electrotechnics, Riga Technical University since 2010. The main research area is renewable energy resources, biofuel and exergy.

Master thesis "Analysis of Long-Term Plan for Energy Supply System for Latvia that is 100\% Based on the Use of Local Energy Resources" was defended in Institute of Energy Systems and Environment, Riga (2010).

Address: Kronvalda blvd. 1, LV-1010, Riga, Latvia

Phone: +371 67089911, Fax: +371 67089908

E-mail: jekaterina.porubova@rtu.lv 


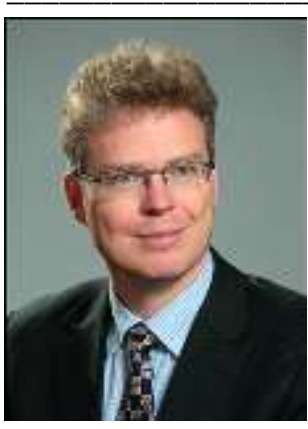

Gatis Bazbauers, Dr.sc.ing., has a diploma of thermal engineering (1990), master of science degree in mechanical engineering (1995), doctor of science degree in engineering (1999) and bachelor's degree in business administration (2002). He works in the Institute of Energy Systems and Environment, Faculty of Energy and Electrical Engineering at Riga Technical University from the year 2000, and currently is a Professor. He worked as a Managing Director in the energy company "Vattenfall Latvia" (1995-2007), as a Project Manager in the energy consulting company "EEE" (1992-1993) and as an Assistant in the Riga Technical University (1990-1993). The main research interests are district heating systems and cogeneration, energy system planning and economics, renewable energy sources, ecodesign, life cycle assessment. Gatis Bazbauers is a member of the council of Latvia's District Heating Association.

Phone: +371 67089911

E-mail: gatis.bazbauers@ @rtu.lv

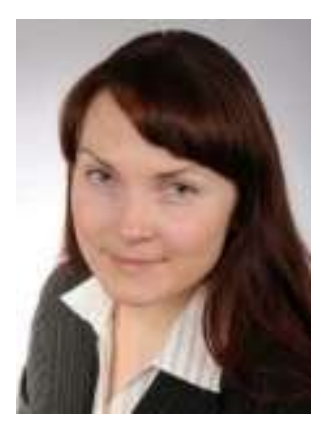

Darja Markova, Dr.sc.ing., senior researcher, Riga Technical University, Environment Protection and Heating Systems Institute. Darja Markova has been part of academic staff of Faculty of Energy and Electrotechnics, Riga Technical University since 2007. The main research topics are district heating, bioenergy systems as well as hydrogen production. She has participated in different local projects related to energy as well as is author of more than 10 publications. She has Bachelor (2003) and Master (2005) of Environmental Science Diploma. PhD thesis "Research of bioethanol reforming and hydrogen production processes for use in fuel cell equipment" was defended in Riga Technical University (2009), where a part of experimental work was carried out during scholarship of German Environmental Foundation in Fraunhofer Institute for Solar Energy Systems (2006).

E-mail: darja.markova@rtu.lv

Jekaterina Porubova, Gatis Bažbauers, Darja Markova. Adiabātiskā un izotermiskā metanācijas procesa modelēšana.

Arvien lielāka uzmanība pasaulē tiek pievērsta globālajām klimata pārmainnām, ko veicina fosilo kurināmo izmantošana. Tajā pašā laikā ir vērojams nemitīgs enerǵijas pieprasījuma pieaugums, kas ierobežota fosilā kurināmā apjoma apstāklos noved pie saražotās enerǵijas izmaksu palielināšanās. Savukārt Latvijas energètikas sektors ir būtiski atkarīgs no fosilā kurināmā importa, bet Eiropas Savienības prasības nosaka to, ka līdz 2020. gadam 10\% no degvielas patēriņa transporta nozarē ir jānodrošina ar biodegvielu. Lai sasniegtu šo mērḳi, ir jāveicina biodegvielas ražošanas attīstība un plašāka izmantošana. Pielietojot dažādus biomasas pārveides procesus, iespējams iegūt dažādus kurināmā veidus: cieto (bio-ogleklis), škidro (biodīzelis un etanols) un gāzveida (biometāns). Biometāns pieder pie otrās paaudzes biodegvielas, jo tā ražošanas procesā kā izejvielas tiek izmantotas lignīnu saturošas vielas (biomasa), kā arī biometāna izmantošanas jomas ir ne tikai transporta sektors, bet arī enerǵêtikas nozare kopumā. Kopējā metāna ražošanas efektivitāte var sasniegt $65 \%$.

Darbā ar Aspen Plus ${ }^{\circledR}$ programmas palīdzību tiek izveidoti trīs metanācijas procesa modeḷi, veikts detalizēts modeḷu apraksts un iegūto datu analīze. Darbs tiek koncentrēts uz to, kā sintezētās gāzes sastāva izmaiṇas (slāpeklis un og̣̣skābā gāze) ietekmē metāna iznākumu. Darbā iegūtie rezultāti liecina par to, ka lielu lomu metāna iznākuma palielināšanā spēēē og̣̣skābā gāze, kā arī, palielinot slāpekḷa koncentrāciju, samazinās metanācijas temperatūra adiabātiskā procesa gadījumā. 